\title{
ANALISIS POTENSI EKONOMI SAMPAH PLASTIK BERDASARKAN JENIS DARI AKTIVITAS KAFE, KANTIN DAN FUTSAL DI KOTA PONTIANAK
}

\author{
Dian Rahayu Jati ${ }^{1}$, Dawud Abullah Azzaki ${ }^{1}$ \\ ${ }^{1}$ Jurusan Teknik lingkungan, Fakultas Teknik, Universitas Tanjungpura \\ Jl. Prof. Dr. H. Hadari Nawawi, Pontianak, 78124
}

Email korespondensi: dianjati@teknik.untan.ac.id

\begin{abstract}
Abstrak
$\underline{10.26418 / \text { pipt.2021.1 }}$

Produksi sampah plastik yang terus meningkat perlu penanganan lebih lanjut karena dapat mengakibatkan permasalahan serius. Nilai ekonomis sampah plastik bisa didapatkan melalui berbagai proses pengolahan, seperti: daur ulang menjadi bijih plastik untuk dimanfaatkan sebagai produk plastik yang baru. Penelitian ini dilakukan pada kafe, kantin, dan gedung futsal yang menghasilkan jenis sampah plastik terutama jenis Polyethylene Terephthalate (PET) dan Polyprophylene (PP). Produk sampah plastik ini kemudian mengkonversikan harga sesuai dengan harga pasar untuk menentukan potensi ekonominya. Pengumpulan data timbulan dan komposisi sampah dilakukan selama satu bulan. Hasil penelitian didapatkan bahwa gelas bening sablon dari jenis PP merupakan jenis sampah yang dominan sebanyak $22,53 \mathrm{Kg}$, diikuti dengan botol bening biru dengan jenis PET seberat $11 \mathrm{Kg}$. Potensi ekonomi dalam kurun waktu per tahun yang didapatkan dari empat lokasi sampel adalah Rp. 915.468.
\end{abstract}

Kata kunci : Sampah Plastik, Potensi Ekonomi, Plastik PP, Plastik PET

\section{PENDAHULUAN}

Produksi sampah plastik yang terus meningkat perlu penanganan lebih lanjut karena dapat mengakibatkan permasalahan yang serius. Indonesia merupakan negara terbesar ke dua penyumbang sampah plastik ke lautan (Jambeck et al., 2015). Sampah plastik memiliki dampak besar terhadap lingkungan karena plastik memiliki sifat tidak mudah terdegradasi (nonbiodegradable). Plastik diperkirakan membutuhkan waktu 1000 tahun agar dapat terdegradasi dengan sempurna. Sampah plastik yang ditimbun di tempat pembuangan akhir dapat mencemari tanah dan air tanah sehingga membahayakan kesehatan makhluk hidup di sekitarnya serta manusia (Chandra, 2009).

Data statistik persampahan domestik Indonesia menyebutkan jenis sampah plastik $14 \%$ dari total produksi sampah, sehingga sampah plastik yang dihasilkan Kota Pontianak sebanyak 56 ton/perhari atau 20.440 ton/tahun (Kholidah dkk., 2019). Permasalahan sampah plastik dapat ditanggulangi dengan daur ulang sampah plastik. Hasil akhir dari proses daur ulang sampah plastik dapat bernilai ekonomi dengan dijual kepada pihak ketiga. Nilai ekonomi sampah plastik Kota Pontianak pada tahun 2016 sebesar Rp. 2.288.134.189 (Asdiantri, 2016). Penelitian ini bertujuan menganalisis potensi ekonomi sampah plastik berdasarkan jenis untuk aktivitas operasional kafe, kantin dan futsal di kota Pontianak.

\section{METODOLOGI}

Objek penelitian adalah aliran sampah plastik berdasarkan aktivitas operasional kafe, kantin dan futsal. Teknik pengumpulan sampah plastik dengan menggunakan metode pewadahan khusus sampah plastik. Pengumpulan sampah plastik dilakukan selama 30 hari dengan pengambilan sampah plastik setiap 7 hari. 


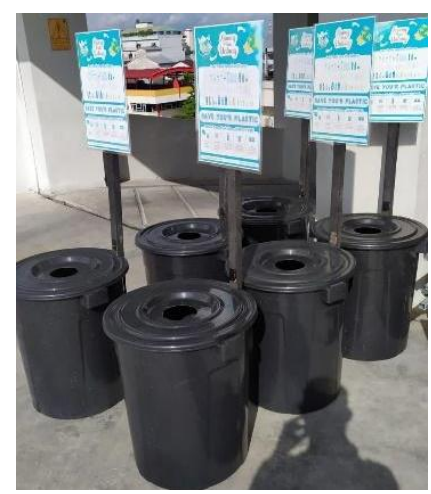

Source: (penulis, 2021)

Gambar 1: Wadah pengumpul sampah plastik

Analisis terhadap data timbulan sampah plastik berdasarkan jenis sampah plastik pada masing-masing aktivitas kafe, kantin dan futsal. Selanjutnya, timbulan sampah plastik dikonversikan dalam satuan harga sesuai dengan harga pasar untuk menentukan potensi ekonominya.

Tabel 1: Nilai ekonomi sampah

\begin{tabular}{|c|c|c|c|}
\hline No & Jenis Sampah Plastik & $\begin{array}{c}\text { Kode } \\
\text { Sampah }\end{array}$ & $\begin{array}{c}\text { Harga } \\
(\mathrm{Rp} / \mathrm{Kg})\end{array}$ \\
\hline 1 & $\begin{array}{l}\text { Botol Bebing } \\
\text { (PETE) }\end{array}$ & $\mathrm{BBB}$ & 800 \\
\hline 2 & Botol Bening (PETE) & $\mathrm{BB}$ & 1.000 \\
\hline 3 & Botol Warna (PETE) & BW & 500 \\
\hline 4 & Botol Putih (HDPE) & $\mathrm{BP}$ & 1.500 \\
\hline 5 & Gelas Bening (PP) & GB & 2.000 \\
\hline 6 & $\begin{array}{l}\text { Gelas Bening Sablon } \\
(\mathrm{PP})\end{array}$ & GBS & 800 \\
\hline 7 & Gelas Warna (PP) & GW & 500 \\
\hline 8 & Tutup Botol (HDPE) & TB & 1.500 \\
\hline
\end{tabular}

Sumber: (Bank Sampah Rossella, 2021)

\section{HASIL DAN PEMBAHASAN}

\section{Analisis Timbulan Sampah Plastik}

Hasil analisis timbulan sampah plastik menggunakan metode pewadahan disajikan pada tabel 2 .

Tabel 2: Timbulan sampah plastik pada aktivitas kafe besar, kafe kecil, kantin, dan futsal

\begin{tabular}{|c|c|c|c|c|c|}
\hline No & Tanggal & $\begin{array}{c}\text { Kafe } \\
\text { Besar } \\
(\mathrm{kg})\end{array}$ & $\begin{array}{c}\text { Kafe } \\
\text { Kecil } \\
(\mathrm{kg})\end{array}$ & $\begin{array}{c}\text { Kantin } \\
(\mathrm{kg})\end{array}$ & $\begin{array}{c}\text { Futsal } \\
(\mathrm{kg})\end{array}$ \\
\hline 1 & $\begin{array}{c}\text { Minggu } \\
\text { ke } 1\end{array}$ & 8,204 & 3,175 & 7,400 & 7,800 \\
\hline
\end{tabular}

\begin{tabular}{|c|c|c|c|c|c|}
\hline 2 & $\begin{array}{l}\text { Minggu } \\
\text { ke } 2\end{array}$ & 7,551 & 2,474 & 6,000 & 6,500 \\
\hline 3 & $\begin{array}{l}\text { Minggu } \\
\text { ke } 3\end{array}$ & 5,416 & 2,400 & 3,740 & 6,800 \\
\hline 4 & $\begin{array}{c}\text { Minggu } \\
\text { ke } 4\end{array}$ & 6,623 & 2,347 & 3,030 & 7,000 \\
\hline \multicolumn{2}{|c|}{ Total sampah } & 27,794 & 10,396 & 20,170 & 28,100 \\
\hline
\end{tabular}

Sumber: (Penulis, 2021)

Hasil analisis terhadap timbulan sampah plastik dengan produksi sampah plastik terbanyak diperoleh pada aktivitas kafe besar pada minggu ke-1 sebanyak 8,204 kg. Untuk total produksi sampah plastik, terbanyak selama 30 hari diperoleh pada aktivitas futsal sebanyak $28,1 \mathrm{~kg}$.

Berdasarkasn hasil analisis produksi timbulan sampah plastik pada aktivitas kafe besar, diperoleh bahwa kantin dan futsal memiliki produksi sampah plastik lebih dari $20 \mathrm{~kg}$. Di sisi lain, sampah plastik pada aktivitas kafe kecil memiliki produksi timbulan kurang dari $20 \mathrm{~kg}$.

Perbedaan produksi timbulan sampah plastik pada setiap lokasi aktivitas dipengaruhi oleh jenis aktivitas yang dilakukan pada setiap lokasi dan luas area pelayanan lokasi aktivitas. Semakin besar area pelayanan maka semakin besar daya tampung konsumen dan berpengaruh pada timbulan sampah plastik yang dihasilkan akan semakin besar.

\section{Analisis Timbulan Jenis Sampah Plastik}

Hasil analisis timbulan sampah plastik berdasarkan jenis plastik disajikan pada tabel 3.

Tabel 3: Timbulan sampah plastik berdasarkan jenis plastik

\begin{tabular}{|c|c|c|c|c|c|c|}
\hline $\begin{array}{c}\mathrm{N} \\
\mathrm{o}\end{array}$ & $\begin{array}{c}\text { Jenis } \\
\text { Samap } \\
\mathrm{h} \\
\text { Plastik }\end{array}$ & $\begin{array}{c}\text { Kafe } \\
\text { Besa } \\
\mathrm{r} \\
(\mathrm{kg})\end{array}$ & $\begin{array}{c}\text { Kafe } \\
\text { Kecil } \\
(\mathrm{kg})\end{array}$ & $\begin{array}{c}\text { Kantin } \\
(\mathrm{kg})\end{array}$ & $\begin{array}{c}\text { Futsa } \\
1(\mathrm{~kg})\end{array}$ & $\begin{array}{c}\text { Total } \\
(\mathrm{kg})\end{array}$ \\
\hline 1 & $\begin{array}{l}\text { Botol } \\
\text { Bening } \\
\text { Biru } \\
\text { (PETE) }\end{array}$ & 2,70 & 1,38 & 7,60 & 11,00 & $\begin{array}{c}22,6 \\
7\end{array}$ \\
\hline
\end{tabular}




\begin{tabular}{|c|l|c|c|c|c|c|}
\hline 2 & $\begin{array}{l}\text { Botol } \\
\text { Bening } \\
\text { (PETE) }\end{array}$ & 2,43 & 0,21 & 8,80 & 10,40 & $\begin{array}{c}21,8 \\
5\end{array}$ \\
\hline 3 & $\begin{array}{l}\text { Botol } \\
\text { Warna } \\
\text { (PETE) }\end{array}$ & 0 & 0 & 2,20 & 4,45 & 6,65 \\
\hline 4 & $\begin{array}{l}\text { Botol } \\
\text { Putih } \\
\text { (HDPE } \\
\text { (HD }\end{array}$ & 0 & 0 & 0 & 0 & 0 \\
\hline 5 & $\begin{array}{l}\text { Gelas } \\
\text { Bening } \\
\text { (PP) }\end{array}$ & 0,14 & 0 & 1,57 & 2,25 & 3,96 \\
\hline 6 & $\begin{array}{l}\text { Gelas } \\
\text { Bening } \\
\text { Sablon } \\
\text { (PP) }\end{array}$ & 22,5 & 8,80 & 0 & 0 & 31,3 \\
\hline 7 & $\begin{array}{l}\text { Gelas } \\
\text { Warna } \\
\text { (PP) }\end{array}$ & 0 & 0 & 0 & 0 & 0 \\
\hline Total sampah & 27,7 & 10,3 & 20,1 & 28,10 & 86,4 \\
\hline
\end{tabular}

Sumber: (Penulis, 2021)

Hasil analisis timbulan sampah plastik berdasarkan jenisnya didominasi oleh sampah plastik gelas bening sablon berjenis Polyprophylene (PP) sebanyak 22,53 kg pada aktivitas kafe besar dan diikuti sampah plastik botol bening biru berjenis Polyethylene Terephthalate (PETE) sebanyak $11 \mathrm{~kg}$. Sedangkan total produksi sampah plastik terbanyak dari seluruh aktivitas diperoleh sampah plastik gelas bening sablon berjenis Polyprophylene (PP) sebanyak $31,34 \mathrm{~kg}$.

Berdasarkan hasil analisis timbulan sampah plastik menurut jenis plastik yang digunakan, aktivitas kafe besar dan kafe kecil didominasi oleh sampah plastik gelas bening sablon berjenis Polyprophylene (PP). Hal ini dikarenakan produksi utama dan fokus pelayanan dari aktivitas kafe berupa minuman khusus dalam kemasan plastik gelas bening sablon. Untuk aktivitas kantin, sampah plastik yang mendominasi adalah botol bening biru dan botol bening berjenis Polyethylene Terephthalate (PETE). Hal ini dikarenakan produksi utama dari aktivitas kantin berupa makanan, dan kemudian disusul dengan produksi minuman dalam kemasan plastik botol. Pada aktivitas futsal, sampah plastik yang mendominasi adalah jenis sampah plastik botol bening biru dan botol bening berjenis Polyethylene
Terephthalate (PETE). Hal ini dikarenakan produksi utama dari aktivitas futsal berupa pelayanan olahraga sehingga produksi sampah tambahan yang ditemukan berupa minuman dalam kemasan plastik botol.

Perbedaan jenis sampah plastik yang mendominasi pada setiap lokasi aktivitas dipengaruhi oleh produksi utama yang di sediakan dan jenis kemasan plastik yang digunakan pada setiap lokasi aktivitas. Semakin besar pelayanan yang disediakan dalam bentuk kemasan plastik khusus maka semakin besar produksi timbulan sampah plastik pada jenis plastik tersebut.

\section{Analisis Nilai Ekonomi Sampah Plastik}

Hasil analisis timbulan sampah plastik dikonversi dengan harga nilai ekonomi sampah plastik berdasarkan jenis plastik disajikan pada tabel 4.

Hasil analisis timbulan sampah plastik dikonversi dengan harga nilai ekonomi sampah plastik berdasarkan jenis plastik. Jenis sampah plastik yang memiliki nilai ekonomi tertinggi sampah plastik gelas bening sablon Polyprophylene (PP) pada aktivitas kafe besar dengan nilai ekonomi senilai Rp 18.024.

Tabel 4: Timbulan sampah plastik dikonversi dengan harga nilai ekonomi sampah plastik berdasarkan jenis plastik.

\begin{tabular}{|c|c|c|c|c|c|}
\hline No & $\begin{array}{c}\text { Jenis } \\
\text { Samaph } \\
\text { Plastik }\end{array}$ & $\begin{array}{c}\text { Kafe } \\
\text { Besar } \\
(\mathrm{Rp}) \\
\end{array}$ & $\begin{array}{c}\text { Kafe } \\
\text { Kecil } \\
(\mathrm{Rp}) \\
\end{array}$ & $\begin{array}{c}\text { Kantin } \\
\text { (Rp) }\end{array}$ & $\begin{array}{c}\text { Futsal } \\
\text { (Rp) }\end{array}$ \\
\hline 1 & $\begin{array}{l}\text { Botol } \\
\text { Bebing } \\
\text { Biru } \\
\text { (PETE) } \\
(\mathrm{Rp} \\
800 / \mathrm{kg})\end{array}$ & 2156 & 1100 & 6080 & 8800 \\
\hline 2 & $\begin{array}{l}\text { Botol } \\
\text { Bening } \\
(\mathrm{PETE}) \\
(\mathrm{Rp} \\
1000 / \mathrm{kg})\end{array}$ & 2434 & 214 & 8800 & 10400 \\
\hline 3 & $\begin{array}{l}\text { Botol } \\
\text { Warna } \\
\text { (PETE) } \\
(\mathrm{Rp} \\
500 / \mathrm{kg})\end{array}$ & 0 & 0 & 1100 & 2225 \\
\hline 4 & $\begin{array}{l}\text { Botol } \\
\text { Putih } \\
\text { (HDPE) }\end{array}$ & 0 & 0 & 0 & 0 \\
\hline
\end{tabular}




\begin{tabular}{|c|c|c|c|c|c|}
\hline No & $\begin{array}{c}\text { Jenis } \\
\text { Samaph } \\
\text { Plastik }\end{array}$ & $\begin{array}{c}\text { Kafe } \\
\text { Besar } \\
(\mathrm{Rp})\end{array}$ & $\begin{array}{l}\text { Kafe } \\
\text { Kecil } \\
(\mathrm{Rp})\end{array}$ & $\begin{array}{l}\text { Kantin } \\
\text { (Rp) }\end{array}$ & $\begin{array}{c}\text { Futsal } \\
\text { (Rp) }\end{array}$ \\
\hline & $\begin{array}{l}(\mathrm{Rp} \\
1500 / \mathrm{kg})\end{array}$ & & & & \\
\hline 5 & $\begin{array}{l}\text { Gelas } \\
\text { Bening } \\
(\mathrm{PP}) \\
(\mathrm{Rp} \\
2000 / \mathrm{kg})\end{array}$ & 270 & 0 & 3140 & 4500 \\
\hline 6 & $\begin{array}{l}\text { Gelas } \\
\text { Bening } \\
\text { Sablon } \\
(\mathrm{PP}) \\
(\mathrm{Rp} \\
800 / \mathrm{kg})\end{array}$ & 18024 & 7046 & 0 & 0 \\
\hline 7 & $\begin{array}{l}\text { Gelas } \\
\text { Warna } \\
(\mathrm{PP}) \\
(\mathrm{Rp} \\
500 / \mathrm{kg})\end{array}$ & 0 & 0 & 0 & 0 \\
\hline & $\begin{array}{l}\text { tal Nilai } \\
\text { konomi }\end{array}$ & 22884 & 8360 & 19120 & 25925 \\
\hline $\begin{array}{r}\mathrm{K} \\
\mathrm{Ni} \\
\end{array}$ & $\begin{array}{l}\text { Total } \\
\text { eselruhan } \\
\text { i Ekonomi }\end{array}$ & \multicolumn{4}{|c|}{76289} \\
\hline
\end{tabular}

Sumber: (Penulis, 2021)

Total nilai ekonomi tertinggi dari produksi seluruh jenis sampah plastik berdasarkan lokasi aktivitasnya yaitu pada aktivitas futsal dengan nilai ekonomi sampah plastik senilai $\mathrm{Rp}$ 25.925. Sedangkan total keseluruhan nilai ekonomi dari produksi sampah plastik semua lokasi aktivitas dalam kurun waktu 30 hari senilai Rp 76.289.

Berdasarkan hasil analisis nilai ekonomi sampah plastik berdasarkan jenis plastik. Dapat dilihat bahwa nilai ekonomi sampah plastik yang dihasilkan oleh aktivitas kafe besar senilai Rp 22.884 dan aktivitas futsal senilai Rp 25.925. Dari kedua nilai ekonomi sampah plastik tersebut tidak jauh berbeda, namun jumlah timbulan sampah plastik dan jenis sampah plastik yang terkumpul pada setiap lokasi aktivitas memiliki perbedaan. Hal ini dikarenakan nilai ekonomi sampah plastik dipengaruhi oleh banyaknya timbulan sampah plastik dan tingginya harga dari jenis sampah plastik tersebut. Semakin banyak timbulan sampah plastik akan diikuti dengan tingginya nilai harga ekonomi sampah plastik mengakibatkan nilai ekonomi yang di dapat bernilai semakin tinggi.

\section{Analisis Potensi Nilai Ekonomi}

Timbulan sampah plastik yang dihasilkan memiliki potensi nilai ekonomi yang tinggi dalam kurun waktu satu tahun.

Tabel 5: Potensi nilai sampah plastik pada lokasi aktivitas kafe besar, kafe kecil, kantin, dan futsal

\begin{tabular}{|c|l|lr|ll|}
\hline No & Lokasi Aktivitas & \multicolumn{2}{|c|}{$\begin{array}{c}\text { Kurun waktu } \\
1 \text { bulan }\end{array}$} & \multicolumn{2}{c|}{$\begin{array}{c}\text { Kurun waktu } \\
1 \text { tahun }\end{array}$} \\
\hline 1 & Kafe Besar & $\mathrm{Rp}$ & 22.884 & $\mathrm{Rp}$ & 274.608 \\
\hline 2 & Kafe Kecil & $\mathrm{Rp}$ & 8.360 & $\mathrm{Rp}$ & 100.320 \\
\hline 3 & Kantin & $\mathrm{Rp}$ & 19.120 & $\mathrm{Rp}$ & 229.440 \\
\hline 4 & Futsal & $\mathrm{Rp}$ & 25.925 & $\mathrm{Rp}$ & 311.100 \\
\hline \multicolumn{2}{|c|}{$\begin{array}{c}\text { Total Nilai Ekonomi } \\
\text { Sampah Plastik }\end{array}$} & $\mathrm{Rp}$ & 76.289 & $\mathrm{Rp}$ & 915.468 \\
\hline
\end{tabular}

Sumber: (Penulis, 2021)

Dari tabel di atas menunjukkan bahwa nilai ekonomi yang dihasilkan dalam kurun waktu satu tahun paling besar diperoleh dari lokasi aktivitas futsal dengan nilai $\mathrm{Rp}$ 311.100. Selain itu, diketahui potensi nilai ekonomi dalam kurun waktu satu tahun yang didapatkan dari empat lokasi sampel adalah Rp. 915.468.

\section{Analisis Potensi Pengolahan Sampah Plastik Menjadi Produk Baru}

Berdasarkan penelitian-penelitian sebelumnya tentang timbulan sampah plastik yang dihasilkan, dibersihkan dan dipilah berdasarkan jenis bahan plastik dapat diolah menjadi beberapa produk yang memiliki fungsi tertentu antara lain:

- Daur ulang sampah plastik menjadi produk biji plastik sebagai bahan dasar pembuatan alat berbahan plastik (Hastarina dkk., 2019).

- Pemanfaatan botol plastik dan sampah plastik lembut menjadi produk ecobrick sebagai bahan material bangunan dan bahan dasar furniture. (Suminto, 2017)

- Pembuatan Bata Plastik sebagai alternatif material bangunan (Reksi dkk., 2021)

- Pembuatan paving block berbahan sampah plastik (Burhanuddin dkk., 2018). 
- Modifikasi campuran aspal menggunakan plastik sebagai material jalan (Fitri dkk., 2018)

- Pembuatan bahan bakar minyak hasil proses pirolisis sampah plastik (Ramadhan \& Ali. 2012).

\section{KESIMPULAN}

Berdasarkan penelitian maka dapat disimpulkan bahwa:

1. Produksi sampah plastik terbanyak diperoleh pada aktivitas kafe besar pada minggu ke-1 sebanyak 8,204 kg. Sedangkan total produksi sampah plastik terbanyak selama 30 hari diperoleh pada aktivitas futsal sebanyak $28,1 \mathrm{~kg}$.

2. Jenis plastik yang mendominasi adalah sampah plastik gelas bening sablon berjenis Polyprophylene (PP) sebanyak $22,53 \mathrm{~kg}$ pada aktivitas kafe besar kemudian diikuti sampah plastik botol bening biru berjenis Polyethylene Terephthalate (PETE) sebanyak $11 \mathrm{~kg}$. Sedangkan total produksi sampah plastik terbanyak dari empat aktivitas diperoleh sampah plastik gelas bening sablon berjenis Polyprophylene (PP) sebanyak $31,34 \mathrm{~kg}$.

3. Jenis sampah plastik yang memiliki nilai ekonomi tertinggi sampah plastik gelas bening sablon Polyprophylene (PP) pada aktivitas kafe besar dengan nilai ekonomi senilai Rp 18.024. Total nilai ekonomi tertinggi dari produksi seluruh jenis sampah plastik yaitu pada aktivitas futsal dengan nilai ekonomi sampah plastik senilai Rp 25.925. Sedangkan total keseluruhan nilai ekonomi dari empat aktivitas dalam kurun waktu 30 hari senilai Rp 76.289.

4. Nilai ekonomi yang dihasilkan dalam kurun waktu satu tahun paling besar diperoleh dari lokasi aktivitas futsal dengan nilai Rp 311.100. Sedangkan potensi nilai ekonomi dalam kurun waktu satu tahun yang didapatkan dari empat lokasi sampel adalah Rp. 915.468.

5. Hasil timbulan sampah plastik yang diperoleh selama penelitian memiliki potensi pengolahan sampah plastik. Selain itu, produk ini juga memiliki fungsi tertentu dan nilai ekonomi yang lebih tinggi.

\section{UCAPAN TERIMA KASIH}

Ucapan terima kasih disampaikan kepada bang Dedy pemilik kafe Satu Hati, bang M. Hafidz pemilik kafe Rumangsa, Pakde Sardoyo dan pak Sartono pengelola Futsal Griya, dan bang Oz (Idrus) beserta rekan pengelola Kantin Kamek FT Untan karena yang sudah bersedia menjadi lokasi pengambilan sampel sampah plastik.

\section{DAFTAR PUSTAKA}

Asdiantri, A., Fitrianingsih, Y., \& Fitria, L. (2016). Analisis Potensi Nilai Ekonomi Sampah Perumahan Kota Pontianak. Jurnal Teknologi Lingkungan Lahan Basah, 4(1), 1-10.

Burhanuddin, Basuki \& Darmanijati, M.R.S. (2018). Pemanfaatan Limbah Plastik Bekas Untuk Bahan Utama Pembuatan Paving Block. Jurnal Rekayasa Lingkungan. (18)1, 1-7

Chandra, Y. (2009). Potensi Kulit Jeruk Sebagai Bahan Pengurai pada Proses Pengolahan Limbah Kantong Plastik. Bogor: IPB.

Fitri, S., Saleh, S.M., \& Isya, M. (2018). Pengaruh Penambahan Limbah Plastik Kresek Sebagai Subsitusi Aspal PEN 60/70 Terhadap Karakteristik Campuran Laston AC BC. Jurnal Teknik Sipil. 1(3).

Hastarina, M., Masruri, A.A., \& Saputra,S.A. (2019). Perancangan Mesin Peleleh Biji Plastik Sebagai Alternatif Pengolahan Limbah Plastik dengan Penerapan Metode Value Engineering. Integrasi Jurnal Ilmiah Teknik Industri. 2(6). 49-54

Jambeck, J.R., Geyer, R., Wilcox, C., Siegler, T.R., Perryman, M., Andrady, A., \& 
Law, K.L. (2015). Plastik Waste Inputs From Land To The Ocean, Science, 347(6223), 768-771.

Kholidah, N., Faizal, M., \& Said, M. (2019). Polystyrene P lastic Waste Conversion into Liquid Fuel with Catalytic Cracking Process Using $\mathrm{Al} 2 \mathrm{O} 3$ as Catalyst. Science \& Technology Indonesia, (3), 1-6

Ramadhan, A. P., \& Ali, M. (2012). Pengolahan Sampah Plastik Menjadi Minyak Menggunakan Proses Pirolisis. Jurnal Ilmiah Teknik Lingkungan. 4(1).
Reksi, M.R., Jati, D.R., \& Fitrianingsih, Y. (2021). Perbandingan Kuat Tekan Bata Plastik Berjenis Polypropylene (PP), Polyethylene Terephthalate (PET) dan High Density Polyethylene (HDPE). Jurnal Teknologi Lingkungan Lahan Basah. 9(1).

Suminto, S. (2017). Ecobrick: Solusi Cerdas Dan Kreatif untuk Mengatasi Sampah Plastik. Jurnal Desain Produk (Pengetahuan dan Perancangan Produk). 3(1). 